\title{
Literature Review on the Relationship between Intellectual Capital and Enterprise Performance
}

\author{
Xianju Si \\ Department of Accounting, Jinan University, Guangzhou, China \\ Email:sxj1120051443@163.com
}

How to cite this paper: Si, X.J. (2019) Literature Review on the Relationship between Intellectual Capital and Enterprise Performance. Modern Economy, 10, 386-398. https://doi.org/10.4236/me.2019.102026

Received: January 7, 2019

Accepted: January 28, 2019

Published: January 31, 2019

Copyright $\odot 2019$ by author(s) and Scientific Research Publishing Inc. This work is licensed under the Creative Commons Attribution International License (CC BY 4.0).

http://creativecommons.org/licenses/by/4.0/

\begin{abstract}
With the advent of the era of knowledge economy, intellectual capital has become one of the important factors to improve the competitiveness and value of enterprises. In recent years, the research on intellectual capital and enterprise performance has become a new hotspot in the field of management accounting. However, because the theoretical basis of intellectual capital is not mature enough, scholars argue about it, and it is difficult to reach a consistent conclusion. On the basis of a brief review of the basic theories of the concept, elements and measurement of intellectual capital, this paper focuses on reviewing the relevant literature on the relationship between intellectual capital and enterprise performance, aiming at pointing out the existing achievements and the remaining shortcomings, and pointing out the direction for further research.
\end{abstract}

\section{Keywords}

Intellectual Capital, Performance, Overview

\section{Introduction}

In the Industrial Revolution of the 18th century, machinery replaced traditional human labor, and the improvement of production efficiency highlighted the importance of productive capital. With the development of economic globalization and high-tech, we have entered a new knowledge-oriented economic era in the 21 st century. The focus of social attention is no longer the traditional factors of production, but the lack of knowledge resources. In this context, the academic circles gradually deepen the research on knowledge resources, and focus on the 
importance of information, knowledge, technology and other intellectual factors to promote economic growth. In today's era of knowledge economy, intangible assets such as knowledge, talent and information have become an important way to enhance the comprehensive strength of enterprises. The competition among enterprises is not limited to traditional natural resources, labor force and production facilities, but emphasizes the core competition based on intangible intellectual capital such as knowledge, intelligence and information. Enterprises have gradually realized the importance of intellectual capital factors in the operation and management of enterprises.

Under the background of knowledge economy, great changes have taken place in the global economic environment. Knowledge and intellectual achievements play a more and more important role in economic development. The unique knowledge possessed by enterprises has become the basis of core competitiveness of enterprises. The driving factors of value creation of enterprises are also changing fundamentally. Traditional material capital is gradually replaced by intellectual capital. The view that the source of enterprise value creation has been generally accepted [1]. In the competitive environment of survival of the fittest, if an enterprise wants to maintain its lasting vitality, it must constantly improve its value creation ability. The effective use of intellectual capital, which condenses knowledge achievements, is the source for an enterprise to realize its value and maintain its competitive advantage. Based on this, the research on the relationship between intellectual capital and corporate performance has gradually become a hot topic for scholars at home and abroad. However, due to the differences in the definition and measurement methods of the concept and components of intellectual capital, there is no consensus on whether intellectual capital can affect enterprise performance and through what mechanism. This paper reviews and evaluates the literature on the correlation between intellectual capital and enterprise performance on the basis of combing the basic theory of intellectual capital, in order to find out the shortcomings of existing research, and bring some enlightenment and reference for the future research of relevant researchers.

\section{An Overview of the Basic Theory of Intellectual Capital}

The research on intellectual capital has gone through three stages. The first stage is the research on the definition and elements of intellectual capital, the second stage is the research on the evaluation methods of intellectual capital, and the third stage is the research on the future application of intellectual capital, which is to link intellectual capital with enterprise performance and combine theory with practice [2]. In my opinion, the first two stages belong to the study of the basic theory of intellectual capital, and are also the basis of the third stage of research, that is, the relationship between intellectual capital and enterprise performance, etc. Therefore, this paper first gives a brief overview of the research results of the first two stages. 


\subsection{The Concept of Intellectual Capital}

In 1969, Calbraith, an American economist, first put forward the term "intellectual capital". He pointed out that intellectual capital is a dynamic capital, a dynamic process of knowledge generation, and a way to achieve goals [3]. However, Calbraith's definition and study of this concept only stay here, without further elaboration. At present, the connotation of intellectual capital lacks a unified standard. Scholars mainly define intellectual capital from three perspectives: intangible assets, knowledge and ability, and enterprise value [4]. In my opinion, intellectual capital can be defined as the sum of knowledge assets that a company owns or controls, which can bring competitive advantages to an organization and create high value. This concept points out that creating high value differentiates intellectual capital from general intangible assets, and emphasizes that intellectual capital is not a single asset. It can play an economic role of $1+1>2$, and is more suitable for the study of the relationship between intellectual capital and enterprise performance.

\subsection{Elements of Intellectual Capital}

Because of the different research perspectives on intellectual capital, scholars at home and abroad have different views on the constituent elements of intellectual capital. There are mainly dualism, trialism and pluralism. Dualism holds that intellectual capital mainly consists of human capital and structural capital. The theory of Trinity holds that intellectual capital consists of human capital, structural capital and relational capital.

\subsection{The Measuring Method of Intellectual Capital}

According to the relevant literature, there are 35 methods to measure intellectual capital. Because of the heterogeneity of the elements of intellectual capital in different industries and different stages, up to now, no one method is generally accepted by the outside world [5]. These 35 methods can be divided into five categories: market value and book value difference method, scorecard method, economic value added method, direct measurement method and intellectual capital value added coefficient method. Among the above methods, the intellectual capital increment coefficient method is a common method used in the current intellectual capital research, and other methods are also involved. Next, it will be elaborated in combination with specific research.

\section{A Summary of the Relationship between Intellectual Capital and Enterprise Performance}

According to the viewpoint of most scholars, the value creation of enterprises has changed from relying on traditional material capital to relying on intellectual capital such as knowledge, technology and innovation. Intellectual capital has become the driving factor of enterprise value creation and plays an important role in improving enterprise performance. Therefore, scholars at home and 
abroad have carried out extensive research on the relationship between intellectual capital and corporate performance. Generally speaking, the research on the relationship between intellectual capital and enterprise performance mainly includes theoretical research on the relationship between intellectual capital and enterprise performance, and empirical research on the relationship between intellectual capital and enterprise performance.

\subsection{Theoretical Research on the Relationship between Intellectual Capital and Enterprise Performance}

Influenced by many factors such as individual, organization and social culture, scholars at home and abroad have carried out theoretical research on whether intellectual capital can improve enterprise performance and through what mechanism to improve enterprise performance.

From abroad, Boilton [6] believes that intellectual capital is regarded as the primary source of competitive advantage and value creation in many knowledge-intensive organizations. Daniel [4] points out that intellectual capital creates corporate wealth through the synergy of human capital, structural capital and relational capital, and that individual capital has only the potential to create corporate wealth. Guthrie [7] separately analyzed the role of human capital and relationship capital in improving enterprise performance, believing that human capital can change customer's view of enterprise, and relationship capital can effectively improve the brand image of enterprise, consolidate customer relationship and enhance enterprise performance. Steven Firer (2003) divides the intellectual value-added coefficient into material capital value-added coefficient, human capital value-added coefficient and structural capital value-added coefficient. Through the research, it is found that intellectual capital has a positive effect on enterprise market evaluation and enterprise profitability enhancement. Nick Bontis [8] argues that human capital, organizational capital and relational capital interact. When an enterprise invests in increasing employees' knowledge or upgrading their skills, Products or services created by employees translate into organizational benefits.

On the domestic side, Fu Chuanrui [9] studied the relationship between intellectual capital and enterprise performance from the perspective of value creation, explored the mechanism of value creation of intellectual capital, and considered that the path of enterprise value creation takes intellectual capital and other capital elements as input and enterprise value as output, which effectively analyzed the relationship between intellectual capital and enterprise performance. Xu Fengju and Zhou Wen [10] made a theoretical analysis on the path of enterprise value creation based on intellectual capital. They pointed out that intellectual capital is an indispensable driving factor for enterprise value creation. It can enhance the sustainability of enterprise, cultivate and enhance the comprehensive competitiveness of the company, influence the future operating income and cash flow of the company, thereby affecting the value of the company and the price of the company's stock. Wangxi and Peng Leiqing [11] discussed 
the operation mode of intellectual capital in social enterprises, pointing out that the three structures of intellectual capital help social enterprises create value by balancing the use of existing and future intellectual resources. Zhang Oman [12] takes knowledge-intensive service enterprises as an example, takes customer participatory innovation as the breakthrough point, uses analytic hierarchy process (AHP) to explore the influencing factors of the operation efficiency of intellectual capital, which draws a conclusion that specialized knowledge and skills, customer information reserve, renewal degree and processing ability have a strong impact on the operation efficiency of intellectual capital and improve corporate performance, under the background of domestic economic upgrading and transformation.

In addition, most scholars agree that intellectual capital plays an important role in corporate performance, but the influence path of intellectual capital on enterprise performance is quite different. Mediating variable and adjusting variable are important variables introduced in mining complex causality. Mediating variables are mediations in which independent variables affect dependent variables; adjusting variable will affect the direction (positive or negative) and strength of the relationship between independent variable and dependent variable. Sun Fanghua and Chen Honger [13] combed the relevant literatures of intellectual capital, and analyzed the three mechanisms of intellectual capital on enterprise performance, that is, intellectual capital directly improves enterprise performance, intellectual capital indirectly affects enterprise performance through some intermediary variables, and the impact of intellectual capital on enterprise performance can be achieved by adjusting variable. Gao Juan and Tang Xiangxi [14] also reviewed the research results of intellectual capital, analyzed the direct, indirect and regulatory effects of intellectual capital on enterprise performance, and put forward suggestions for the related research of intellectual capital.

Summary: From the theoretical research on intellectual capital and enterprise performance management at home and abroad, it can be divided into two categories: one is to examine the relationship between intellectual capital and enterprise performance from the perspective of intellectual capital as a whole. This kind of research generally believes that intellectual capital is beneficial to the creation of enterprise value and has a positive correlation with enterprise performance. However, this kind of research neglects the relationship between the elements of intellectual capital and only sees the final results. There are many criticisms in the theoretical interpretation. The other is to examine the relationship between intellectual capital and enterprise performance from the perspective of various elements of intellectual capital. It is believed that there are synergistic effects among the elements of intellectual capital, which act on enterprise performance together, and its mechanism is discussed theoretically. However, due to different perspectives and different analytical environments on the constituent elements of intellectual capital, there is no unanimous conclusion as to what impact various elements have on enterprise performance, how and how 
much impact they have.

\subsection{The Empirical Study on the Relationship between Intellectual Capital and Enterprise Performance}

In empirical research, scholars at home and abroad use different measurement methods to measure intellectual capital, select data from different regions and industries, and study the relationship between intellectual capital and enterprise performance. However, they draw different conclusions. This paper classifies them from the perspective of research conclusions.

\subsubsection{Intellectual Capital Is Positively Correlated with Firm Performance}

In empirical research, some scholars at home and abroad think that intellectual capital and corporate performance are significantly positively correlated from the overall perspective of intellectual capital. For example, Ahmed Riahi-Belkaoui [15] used trademark holdings as an alternative variable to intellectual capital. An empirical study was conducted on multinational corporations in service and manufacturing industries in the United States. It was found that intellectual capital had a positive impact on corporate performance. George Tovstiga and Ekaterina Tulugurova [16] studied the impact of intellectual capital on the corporate value of some small innovative enterprises in Russia by means of questionnaires, and reached the conclusion that intellectual capital can promote the corporate value.

However, more and more scholars at home and abroad from the perspective of the interaction of the elements of intellectual capital, through empirical research, have found that the elements of intellectual capital are significantly positively correlated with corporate performance. Bontis [17] used questionnaire survey and principal component analysis to study the relationship between intellectual capital and corporate performance in Canada and Malaysia. It was found that while human capital, structural capital and customer capital affect each other, intellectual capital also has a significant positive effect on corporate performance. Wang Tao, Liu Nianbo and Huang Gan [18] also studied the governance performance of private enterprises by intellectual capital and financial capital through questionnaire survey, and concluded that structural capital has the greatest effect on the performance of private enterprises.

In addition, most scholars use VAIC method to study, such as Ahangar [19] using VAIC method to measure the level of intellectual resources of enterprises, through the construction of regression model, it is confirmed that intellectual capital is a significant role in the change of performance level. Amitava Mondal, Santanu Kumar Ghosh [20] used VAIC method to study the relationship between performance and intellectual capital of 65 leading Indian banks, and found that intellectual capital of banks is essential to competitive advantage. Yang Manli [2] takes the annual report data of 95 listed companies in China's automobile manufacturing industry from 2008 to 2011 as a sample, and draws 
lessons from the model of intellectual capital increment coefficient. The empirical results show that material capital, human capital and structural capital have positive effects on corporate performance. Other scholars adopt other methods to draw similar conclusions. Nanxing Xingxing, Yang Jing and Qupeishing [21] selected A-share listed companies from 2007 to 2012 as samples, and used factor analysis to analyze the correlation between intellectual capital investment and enterprise operation efficiency from the perspective of intellectual capital investment, and concluded that there is a positive impact on the investment of intellectual capital and enterprise operation efficiency. Among them, human capital plays the most important role.

\subsubsection{There Is No Significant or Negative Correlation between Intellectual Capital and Firm Performance}

Some scholars have found that the relationship between intellectual capital and corporate performance is not obvious or even negative. Overseas, Sriranga Vishnu, Vijay Kumar Gupta [22] used VAIC method to study the correlation between intellectual capital and corporate performance of Indian pharmaceutical companies. Two scholars proposed to improve the VAIC model by adding relational capital (RC) into the model, but the empirical results were not satisfactory, and did not prove that relational capital significantly affected corporate performance. Daniel Pitelli Britto, Eliane Monetti, Joao Da Rocha Lima Jr. [23] used VAIC method to analyze the data of Brazilian Real Estate Company from 2007 to 2011. It was found that there was a significant reverse relationship between intellectual capital and market value. The higher the value of the company, the lower the level of intellectual capital.

Domestically, Li Jiaming and Li Fubing [24] have found that physical capital has a significant positive effect on corporate performance, while human capital has not a significant positive effect on corporate performance, while structural capital has a negative effect on corporate performance. Wangxi [25] used VAIC and correlation analysis and multiple regression analysis to make an empirical analysis of the best operating companies in China in 2003. The results show that there is a significant positive correlation between material capital and corporate performance, and that structural capital and human capital also have a positive contribution to corporate performance, but not statistically significant.

\subsubsection{Different Relations between Intellectual Capital and Enterprise Performance}

Throughout the literature at home and abroad, more and more scholars have come to the conclusion that the relationship between intellectual capital and corporate performance is different. Some scholars believe that the relationship between intellectual capital and enterprise performance in different industries is different. For example, Stevo Pucar [26] used VAIC method to conduct an empirical study on exports of 134 companies in Bosnia and Herzegovina. It was found that intellectual capital and its components had a significant positive impact on export growth of food, beverage, furniture and woodwork manufacturing 
industries, while other industries had no significant relationship. Iuliia Naidenova, Petr Parshakov [27] argues that there are differences between intellectual capital investment activities and enterprise performance. In the Russian retail and steel industries, human capital has a positive impact on economic efficiency, and there is interaction between different components of intellectual capital in the steel and telecommunications industries. Yang Xiaodan and Yan Chao [28] found that for the traditional technology industry in Jiangxi Province, the improvement of its performance mainly depends on structural capital, and human capital has little effect on it; while the improvement of high-tech enterprise performance mainly depends on material capital and human capital, and structural capital basically does not play a role. Wang Ling and Sun Hejie [29] used VAIC method to study 336 sample enterprises of representative bio-pharmaceutical industry and 208 sample enterprises of textile and garment industry, and drew the conclusion that each component factor of intellectual capital has different influence on the performance of different industries.

In addition, many scholars divide the elements of intellectual capital into different categories, and conclude that the relationship between different elements of intellectual capital and enterprise performance is not the same. Mahesh Joshi et al. [30] used VAIC method to select the data of Australian financial industry from 2006 to 2008 to conduct an empirical study on the relationship between intellectual capital and corporate performance. The study found that the performance of Australian financial industry is largely influenced by human capital. Yu Haizong and Deng Qian [31] made an empirical analysis of the listed companies in China's high-tech industry and textile and apparel industry, and concluded that the material capital value-added rate and human capital value-added rate of the companies in the two industries were significantly positively correlated with the performance of the enterprises, while the structural capital value-added efficiency was significantly negatively correlated with the performance of the enterprises. Similarly, we draw the conclusion that human capital is positively correlated with corporate performance, and structural capital is negatively or not significantly correlated with corporate performance. We also draw the conclusion that Luxin and Huangshun [32] studied the listed companies in manufacturing, information technology and real estate industries in the A-share market of Shenzhen and Shanghai Stock Exchanges. Based on the data of five listed banks from 2004 to 2008, Wu Xiaolei [33] made an empirical study on the relationship between intellectual capital and commercial bank performance using panel data. Liu Yuqin [34] used VAIC method, selected A-share listed companies in Shenzhen as research samples, and established a model for empirical analysis. Tang Yongjun and Zhao Zhizhi [35] used Public model to conduct an empirical study on the relationship between various elements of intellectual capital and enterprise performance in power industry.

On the contrary, some scholars have come to the conclusion that structural capital is positively correlated with enterprise performance. For example, Zheng Liping and Zhu Ping [1] took small and medium-sized listed companies in 
Jiangsu and Zhejiang as samples, and concluded that human capital, structural capital and enterprise value are significantly positively correlated. Relational capital and enterprise value are not significant, and the dimensions of intellectual capital influence each other, and work together to create enterprise value. [1] [2]. Sun Lei [36] studied the relationship between human capital, customer capital, structural capital and audit performance of top 100 accounting firms in China. The results show that human capital has little effect on financial performance; structural capital has a relatively obvious impact on its profitability, and customer capital is an important asset of accounting firms.

Summary: Comparing with the existing empirical studies, we can see that there is no consistent conclusion about the relationship between intellectual capital and enterprise performance. This is mainly due to the following reasons: 1) the industries and regions studied are different. Empirical studies at home and abroad are often conducted in the context of specific regions and industries. Because of the differences of sample data between regions and industries, the conclusions will be different. 2) There are different views on the constituent elements of intellectual assets. Researchers based on dualism are Yu Haizong, Deng Qian [31], Lu Xin and Huang Shun [32]. Scholars based on dualism are Sriranga Vishnu, Vijay Kumar Gupta [22], Zheng Liping, Zhu Ping [1], Tang Yongjun and Zhao Hui [35]. Because of the different division of the elements of intelligence, there will be differences in the calculation of intellectual capital and its elements and interactions. 3) The measurement methods of intellectual capital are different. In the above empirical research, Bontis [17], Wang Tao, Liu Nianbo and Huang Gan [18] used questionnaire to measure intellectual capital directly, Ahangar [19], Mahesh Joshi [30], Wang Xi [25]. Liu Yuqin [34] and others used VAIC method to measure intellectual capital, while some scholars such as Ahmed Riahi-Belkaoui [15] sought trademark holdings as alternative variables to intellectual capital. 4) the performance measurement indicators of enterprises are different. Most researchers use ROE [32] [34] as the explanatory variable to measure corporate performance. Other indicators such as Tobin $\mathrm{Q}$ [1], natural logarithm of income [36] and a combination of indicators [18] [35] are also used to measure enterprise performance. In short, because there is no consensus on the elements of intellectual capital and measurement methods in the theoretical circles, there are many disputes about the rational measurement of enterprise performance. Therefore, the existing empirical research needs to be standardized from the theoretical perspectives of method and variable selection.

\section{Conclusion and Suggestion}

This paper reviews the research literature on the relationship between intellectual capital and enterprise performance. It can be seen that scholars at home and abroad have conducted extensive research on the relationship between intellectual capital and enterprise performance. Most scholars believe that there is a positive correlation between the whole intellectual capital and its components and enterprise performance. However, it can also be seen that due to the differ- 
ent industries and economic environment, even if the same industry studies the data of different years in the industry, the conclusions are not entirely consistent, so a few scholars have reached the opposite conclusion. From the theoretical point of view, the impact of human capital, structural capital and relational capital on different industries and enterprises with different performance levels, and the mechanism of intellectual capital's effect on enterprise performance have not reached a consensus in academic circles. The research on the interaction of intellectual capital's elements on enterprise performance is relatively rare. There are many methods to measure intellectual capital. Whether the choice of various methods can truly and effectively measure intellectual capital remains to be studied. From the empirical research point of view, it mainly focuses on specific industries or regions, does not seriously distinguish the life cycle stages of different enterprises, lacks the systematic industry analysis and research based on the life cycle, and the conclusions often lack universality. In addition, the diversified selection of enterprise performance indicators makes the research conclusions lack comparability. A single performance index can only reflect one aspect of the performance of an enterprise in the process of operation, but it can not comprehensively examine the benefits and development potential of the whole enterprise. It is also vulnerable to the impact of accounting manipulation and other issues, resulting in unreliable results.

Based on the understanding of the deficiencies in the relationship between intellectual capital and corporate performance, the author makes further research and suggestions from the following aspects: 1) What kind of mechanism does intellectual capital affect corporate performance, whether through direct effect, intermediary effect or moderating effect, foreign scholars have not reached a consistent conclusion. Which factors will affect the relationship between intellectual capital and enterprise performance, and whether the relationship between the elements of intellectual capital will affect the mechanism of action; these issues provide a new opportunity and direction for follow-up research. 2) There are 35 methods for measuring intellectual capital. Most of the previous studies at home and abroad adopt VAIC method. VAIC method can reflect the increment of intellectual capital in enterprises to a certain extent. The greater the increment coefficient of intellectual capital, the higher the increment efficiency of intellectual capital, the greater the role of intellectual capital. The results of different methods are quite different, which method is more suitable for evaluating the intellectual capital of a particular industry needs to be further explored. 3) The selection of enterprise performance evaluation indicators has a great impact on the research of the relationship between intellectual capital and enterprise performance. Previous studies mainly focused on financial indicators, ignoring the strategic role of intellectual capital in enterprise value creation. Intellectual capital, as an important strategic resource, will be more convincing if it is combined with the research on the correlation of enterprise strategic performance evaluation system. 4) The samples used in the existing studies are relatively single. In the future study, we can further define the life cycle stage of the 
research object, consider the lagging effect of intellectual capital investment on the future performance of enterprises, and conduct case studies to make the research conclusions more comparable and convincing.

\section{Acknowledgements}

Xianju Si wants to thank, in particular, the patience, care and support from her boyfriend, Zelin Luo.

\section{Conflicts of Interest}

The authors declare no conflicts of interest regarding the publication of this paper.

\section{References}

[1] Zheng, L. and Zhu, P. (2014) Research on the Impact of Intellectual Capital on the Value of Small and Medium-sized Enterprises-Data from Zhejiang Province. Communication of Finance and Accounting, 18, 43-45.

[2] Yang, M. (2013) An Empirical Study on the Impact of Intellectual Capital on Corporate Performance-A Case Study of China's Automobile Manufacturing Listed Companies. Friends of Accountants, 22, 53-56.

[3] Xu, X. (2014) The Relation between Emerging Capital and Enterprise Performance. Journal of Guangdong University of Finance and Economics, 1, 22-34.

[4] Andriessen, D. (2001) Weightless Wealth: Four Modifications to Standard IC Theory. Journal of Intellectual Capital, 2, 204-214. https://doi.org/10.1108/14691930110399941

[5] Gao, J. and Tang, J. (2012) Invisible Assets Accounting Theory: Evolution and Development. Financial Communication, 7, 125-127.

[6] Boulton. (2000) The Influence of Intellectual Capital on Export Performance. Journal of Intellectual Capital, 12, 248-261.

[7] Guthrie, J., Petty, R. and Ricceri. F. (2007) Intellectual Capital Reporting: Lessons From Hongkong and Austria. The Institute of Chartered Accountants of Scotland.

[8] Bontis, N, Keow, W.C.C. and Richardson, S. (2013) Intellectual Capital and Business Performance in Malaysian Industries. Journal of Intellectual Capital, 1, 85-100. https://doi.org/10.1108/14691930010324188

[9] Fu, C. (2009) Research on Enterprise Value Evaluation Based on Intellectual Capital. Xiamen University, Xiamen.

[10] Xu, F. and Zhou, W. (2010) Research on Enterprise Value Creation Path Based on Intellectual Capital. Financial Communication, 34, 44-45.

[11] Wang, X. and Peng, L. (2011) Research on Innovation Process of Social Enterprises Based on Intellectual Capital. Management World, 6, 180-181.

[12] Zhang, A. (2015) Research on the Influencing Factors of the Operation Efficiency of Intellectual Capital from the Perspective of AHP Method. Friends of Accounting, $21,88-90$.

[13] Sun, F. and Chen, H. (2009) A Review of Intellectual Capital and Its Impact on Corporate Performance. Southeast Asia, 6, 92-95.

[14] Gao, J. and Tang, X. (2014) Functional Mechanism of Intellectual Capital: Direct Effect, Indirect Effect and Regulatory Effect. East China Economic Management, 6, 
106-111.

[15] Riahi-Belkaoui, A. (2003) Intellectual Capital and Firm Performance of US Multinational Firms: A Study of the Resourced-Based and Stakeholder Views. Journal of Intellectual Capital, 4, 215-226. https://doi.org/10.1108/14691930310472839

[16] Tovstiga, G. and Tulugurova, E. (2007) Intellectual Capital Practices and Performance in Russian Enterprises. Journal of Intellectual Capital, 8, 695-707. https://doi.org/10.1108/14691930710830846

[17] Bontis, N., Keow, W.C. and Richardson, S. (2000) Intelieetual Capital and Business Performance in Malaysian Industries. Journal of Intellectual Capital, 1, 85-100. https://doi.org/10.1108/14691930010324188

[18] Wang, T., Liu, N. and Huang, G. (2010) Empirical Study on Intellectual Capital and Governance Performance of Private Enterprises. Financial Communication, No. 27, 92-95, 161.

[19] Ahangar, F. (2011) The Principal-Agent Problems in Health Care: Evidence from Prescribing Patterns of Private Providers in Vietnam. Health Policy and Planning, 26, i53-i62.

[20] Amitava, M. and Santanu, K.G. (2012) Intellectual Capital and Financial Performance of Indian Banks. Journal of Intellectual Capital, 13, 515-530.

[21] Nan, X., Yang, J. and Qu, P.S. (2015) Study on the Relevance between Intellectual Capital Investment and Enterprise Operating Efficiency-Empirical Analysis Based on Operating Efficiency Evaluation Index System. Financial Communication, No. 6, $103-107+129$.

[22] Vishnu, S. and Kumar, G.V. (2014) Intellectual Capital and Performance of Pharmaceutical Firms in India. Journal of Intellectual Capital, 15, 83-99.

https://doi.org/10.1108/JIC-04-2013-0049

[23] Daniel, P.B. and Eliane, M. (2014) Intellectual Capital in Tangible Intensive Firms: The Case of Brazilian Real Estate Companies. Journal of Intellectual Capital, 15, 333-348.

[24] Li, J. and Li, F. (2004) Empirical Analysis of Enterprise Intellectual Capital and Enterprise Performance. Journal of Chongqing University, 12, 134-138.

[25] Wang, X. (2006) An Empirical Analysis of the Contribution of Intellectual Capital to the Best Operating Companies in China. Nankai Management Review, No. 3, 55-60.

[26] Stevo, P. (2012) The Influence of Intellectual Capital on Export Performance. Journal of Intellectual Capital, 13, 248-261.

[27] Iuliia, N. and Petr, P. (2013) Intellectual Capital Investments: Evidence from Panel VAR Analysis. Journal of Intellectual Capital, 14, 634-660.

[28] Yang, X. and Yan, C. (2011) Study on the Effectiveness of Intellectual Capital Driven Enterprise Performance Improvement-Based on the Data of Jiangxi Listed Companies. Monthly Journal of Finance and Accounting, 15, 13-15.

[29] Wang, L. and Sun, H. (2012) Research on the Impact of Intellectual Capital on the Performance of Listed Companies-Take Biomedicine, Textile and Garment Industry as an Example. Monthly Journal of Finance and Accounting, 30, 33-37.

[30] Mahesh, J., Daryll, C., Jasvinder, S. and Monika, K. (2013) Intellectual Capital and Financial Performance: An Evaluation of the Australian Financial Sector. Journal of Intellectual Capital, 14, 264-285.

[31] Yu, H. and Deng, Q. (2007) Empirical Analysis of Intellectual Capital's Contribution to Corporate Value. Financial Newsletter (Academic Edition), No. 7, 101-103. 
[32] Lu, X. and Huang, S. (2009) Effectiveness of Intellectual Capital-Driven Enterprise Performance: Empirical Analysis Based on Manufacturing, Information Technology and Real Estate. Accounting Research, No. 2, 68-74 + 94.

[33] Wu, X. (2010) An Analysis of the Impact of Intellectual Capital and Material Capital on the Performance of Commercial Banks-Taking Listed Commercial Banks as an Example. Financial Communication, 20, 48-49.

[34] Liu, Y. (2014) Research on the Impact of Intellectual Capital on Enterprise Performance. Financial Communication, 27, 86-88.

[35] Tang, Y. and Zhao, Z. (2015) Intellectual Capital, Equity Nature and Corporate Performance: An Empirical Analysis Based on Public Model of Electric Power Enterprises. Monthly Journal of Finance and Accounting, 24, 29-33.

[36] Sun, L. (2014) Empirical Research on Intellectual Capital Management and Audit Performance of Accounting Firms. Accounting Newsletter, 12, 11-14. 